\title{
Classroom Management: Glocalized Contexts
}

\author{
Manda Pokharel \\ Kathmandu University School of Education, Nepal \\ e-mail: manda.pokharel@gmail.com \\ Mani Ram Sharma \\ Mahendra Ratna Campus,Tahachal (TU) Nepal \\ e-mail: smaniram125@gmail.com \\ Article History: Received on 18 March 2021, Revised on 28 March 2021 \\ Published on 27 July 2021
}

\begin{abstract}
This research based article discusses on issues and practices of classroom management from the local perspectives. It is based on the context of public school of Nepal. The participant is an EFL teacher of public school in Kathmandu, teaching in middle school and secondary level there. The classroom management practices in the EFL teacher's classes are seen using classroom observation tool, in her classes of both the levels for a week using qualitative framework. The findings show the traditional practice still dominating the classroom activities. Therefore the article is based on the issues of classroom management being specific to the seating arrangements, discipline, peer work, group work, space, presentation, and time management in the public school where classroom observation has been done.
\end{abstract}

Keywords: EFL Teacher, Classroom Management, Glocalized Context

\section{A. Introduction}

Being within the real local context of teaching and reading different theories and perceptions of the classroom environment has made teaching a challenging job. The ideal classroom we have is completely different from what the real classrooms are supposed to be. However as classroom management aims to establish a quiet and calm learning environment (Doyle, 1986) leading to the appropriate social and moral development of the learners, it is one of the influential learning factors. Similarly, with foreign researches, a completely different and ideal classroom is presented, where the reality check is different in our context. For instance, the classroom size is not wide enough to accommodate the number of students where traditionally structured classroom settings and planning yet exist here. Furthermore, the students of any level use the same infrastructures.

Classroom management an intended practice to ensure students with more opportunities to learn the things the teacher does to organize class (Nagler, 2016) so that effective learning can take place, is a matter of concern in both academic and professional life. But our outdated practices regarding seat management, classroom structure, activities, presentation, mixed ability grouping of students, and time management are yet the bitter reality of prevailing classroom practices, specifically in public schools.

I observed the classroom of an EFL teacher teaching to the students of class seven and eleven in the public school of Kathmandu for a week. Based on the observation of her classes at both 
Volume 2 (1) 2021

E-ISSN: 2723-6919 P-ISSN:2746-0827

levels and reflecting upon my practices of teaching at the secondary level. The main purpose of this article is to explore the differences in the classroom management practices of middle school level and higher secondary level

\section{Classroom Management}

The challenge of forming tomorrow's $21^{\text {st }}$ century generation has become a big challenge in this world with the expansion of the internet and technology. This sense of the possibility of doing and being everything has made the classroom a complex and challenging milieu. This is where a proper and managed classroom with a well understanding facilitator is needed. This has given rise to the need for proper classroom management with the need of addressing local issues from the global experience, exchanging ideas, and academic knowledge. This is where there is a need to see global classroom management from local perspectives.

Classroom Management is a broad area that carries confusion with it. Though, the area with greater confusion has become an area of interest for all the educational scholars. Confusion because classroom management is realized as an important topic to be dealt with, new teachers beginning their teaching carrier are much worried about it still they are not well aware of 'how' aspect of it. Burns and Richards (2009) use the term "reality shock" (Veenman, 1984:143) to show the situation of novice teachers from teacher education programs to the practice field in the classroom. The classroom realities replace the theoretical premises, by which the novice teachers are in the state of "sink or swim" (Varah, Thune \& Parker 1986). The novice teachers are trained before they land onto the field of teaching, but when they are in practice in the actual classroom, the situation is different; what they had learned and what they face is different.

On the other hand, teacher training also didn't give adequate guidance and programs to beginner teachers on how to manage the students' anxiety level and give their best in the classroom. When these novice teachers don't find solutions to their problems on the field, they either quit the job with a lack of job satisfaction or will be struggling with it throughout, as our teachers seem to be doing. Likewise, the other part is the support they get from their teacher colleagues, the mentoring they receive.

Classroom management was not the much-prioritized area before. But the situation has been changing as the focus is being given to a positive learning environment, how students learn, and how teachers teach is dependent on what sort of environment the teaching-learning activity is going on. As a result number of researches have been done in this area. However, there is a need of doing researches on classroom management in our local context.

Shindler (2010), describes classroom management as transforming class to a better place for a better life, that might differ from school to school and suggests choices we might prefer to have in our class as promote community or fragmentation, lead to clarity or confusion, create a psychology of success or one of failure, be a liberating influence or perpetuate an unjust social class structure, foster motivational and joyful climate or of disinterest and drudgery. Therefore what we do and how we behave determines what we opt for.

The ultimate notion of classroom management is to improve school education and provide quality. However, classroom management in the traditional days was limited only to the physical setting of the classroom. But now it has expanded its horizon from the physical to the mental and psychological environment of the classroom, keeping students at the focal point as 
Volume 2 (1) 2021

E-ISSN: 2723-6919 P-ISSN:2746-0827

the main concern of the teaching-learning process. Davis (2018) in his foreword series has mentioned that classroom management is being perceived in two ways: outside of school factors and in-school factors. Outside of school factors find socio-economic factors responsible for the improvement of education of the children as social surrounding, family background, culture, and parents' consciousness matter the classroom environment. Whereas in school factors take no excuses approach that focuses on issues within schools and contends that poverty is not the primary reason for the achievement in education. They focus on school reform programs, teacher quality, classroom maintenance, and funding aspects.

Globalization of English language and has coined a term for it as glocalization. Patel \& Lynch, (2013) writes, "Glocalization advocates a positive learning experience and encourages the enhancement of learners' glocal experience through a critical academic and cultural exchange of global and local socio-economic and political issues" (p. 223). Learning becomes fruitful when it is related. When learners' learning is related to their socio-cultural and political issues and the sharing of academic and cultural values there with the local and global connections then the learning is positive. This helps the learners to establish their identity and explore experience through global and local issues.

According to the dictionary meaning, the term "glocal" and the process noun "glocalization" is "formed by telescoping global and local to make a blend" (The Oxford Dictionary of New Words, 1991:134 quoted in Robertson, 1995:28). It can be defined as promoting local benefits by its use but at the same time developed to the extent of mixing global criteria or global popularity. Thus glocalization can be said as an outcome from the blend of local issues with the flavor of global. Glocalization here addresses the local issues taking global theories on classroom management into consideration. As Patel and Lynch (2013) write glocalization also teaches to exchange respectful cultural wealth. As we believe that all schools have their own culture of school management, where glocalization helps to exchange and share the effective practices of schools and also respect their cultural values. Thus what can be said is glocalization helps in the integration of cultural values of different schools in a respectful way.

\section{Components of Classroom Management}

Being a widely dominating area in the field of education, classroom management consists of various components like structure and organization, age and classroom management, learners' autonomy, teacher interaction, classroom interaction, active listening of teachers and students, ability grouping in the class, discipline, psychology towards self, time management, seating arrangements, group work, pair work, presentation, time management and many more. However, we will be looking at a few of them from the glocal perspective of classroom management.

One of the many important notions regarding classroom management is discipline: a buzz word. It is regarded as a synonym for classroom management. Changing classroom demands a better management strategy, that is, better strategies lead to better classroom discipline. In the past discipline meant to punish students, but now it is to teach self-control to them not punish. Now through teaching discipline students are being taught to become self-learners, autonomous as well as take responsibility for learning. According to Cummings (2000), the more students are exposed to tasks the more active they become, focused, and self-motivated them leads to establishing discipline. Lewis (2009) says that primary level teachers hardly punish students in the name of misbehavior and discipline compared to secondary level teachers, who are found 
Volume 2 (1) 2021

E-ISSN: 2723-6919 P-ISSN:2746-0827

yelling at students more angrily and punishing them. As we notice the same in our context too. Students at the secondary level misbehave and they are either send to the principal's office or scolded for such behavior. Whereas in the primary level we try and persuade them, make counsel them, or behave softly.

Discipline is regarded as one of the major problems in public schools. Charles (1981, p. 13) points out the harsh realities of classrooms as cited in Tauber $(2007$, p.4) as: Discipline, class control, classroom management by whatever name you call it keeping order in the classroom is a teacher's greatest concern. You may not like that fact; you may wish it weren't true. But it is. That's a given in the daily life of teachers. Discipline is so crucial, so basic to everything else in the classroom that most educators agree: it is the one thing that makes or breaks teachers.

Moreover, when it comes to a new teacher, discipline becomes the biggest challenge. Therefore unless teachers are well trained on the strategies to control disruptive behaviors and discipline and classroom management, this challenge will be there and teachers will be facing this as the most challenging factor in maintaining classroom management.

Time is very important, it waits for nobody. How we use our time is up to us. For the teacher, it means breaking the whole period time for teacher talk and eye contact, group work, peer work, group interaction, and making students work independently. Time management also means planning. Time management plays a vital role in classroom management.

We are still in the traditional way of teaching, where teachers are the bank of knowledge and students the recipient only. Cummings (2000) defines FOCUS as, " $\mathrm{F}=$ face the speaker, $\mathrm{O}=$ organize, $\mathrm{C}=$ connect, $\mathrm{U}=$ use questions, $\mathrm{S}=$ see pictures (p.34)". The content is focused on more than students. We waste time briefing content then making students speak. Teachers enter inside the classroom a few minutes late and get out of the class a few minutes early or later. Teachers directly start teaching or dealing with the contents. There are no warm-up activities, students are talking on their own, are passive and few answer actively. This has been the local practice a few years back when I was in school.

Space and room arrangement have a direct impact on classroom management. But in the context of public schools classroom arrangement and space are limited. However much emphasis is given on content, teachers find it difficult to involve students in tasks to make them do group activities. The more focus would be on the task, the better listeners the students would become. Still, the teacher can lessen the distractions by teacher talk or giving them pair work or small group work. The traditional seat plan is more challenging at the higher secondary level.

Age and classroom management is one the serious issue in our context. The teacher needs to understand the relationship between age and classroom management, as our classes have students of varying ages, especially at the higher secondary level. The strategies used for the classroom vary according to the level of students i.e. age. As Scarlet $(2015$, p. 16) says, "the difference between middle school and high school may appear greater than the similarities, concerning to classroom management they share important features".

Identity issues and feelings persist with the child of this period regarding gender, ethnic identity, physical qualities, and height which is important for the teachers to understand. How students behave is also determined by these factors. They are hyper-alert about their appearances and how others speak to them. 
Volume 2 (1) 2021

E-ISSN: 2723-6919 P-ISSN:2746-0827

Also, the students at higher levels are more rude and disruptive compared to the primary. It is because of the change they are going through. Teaching this group of students is a challenge. As Scarlet (2015) says, it requires 5 things to be done and they are, maintaining students' attention, giving each student opportunities to respond, providing feedback for students' responses, motivating students learning, and preventing and dealing with disruptive behavior. When a teacher follows these strategies they can handle the students with different age groups and behavior.

The other factor that comes with classroom management is seating arrangements. The most widespread instance of visual distraction occurs in the classroom where students are seated around tables looking at one another during teacher talk (Bradford, 2000). While saying this I have seen most of the public schools with the traditional seat planning with desks and benches loaded with four to five students in each. How students seat or how their seats are planned matter a lot in the quality achievement.

The other component is group work, a much-prioritized factor responsible for effective classroom management. Keeping students engaging during teaching-learning activities is important. Keeping engaged is possible with tasks. But while making them do a task the teacher needs to divide the students into small groups, this will help the teacher to get access to all the students. This has many benefits as students involve themselves in interaction, they become active listeners, there is a dialogue in between them that helps to develop critical thinking, students become responsible, and develop a classroom community environment. However, the number of students has become a challenge for the teachers to make students participate in group work.

Learners' autonomy is another factor, we need to consider. But oppositely we are making them dependent on teachers. We still traditionally teach them to do spoon-feeding. Students must be taught how to learn first, that is, teaching them to question, to suppose, and to discover and identify gaps as scientists do. If these can be developed on to students, students become autonomous and feel democratic to learn.

Teaching to learn, teachers can play the role of democratic authoritarian. Authoritarian also because students these days feel they can take care of what is right and wrong as they know their rights, but the problem is they cannot differentiate between rights and responsibilities. This is where they need teachers and proper guidance. This democratic guidance by the teacher leads to interaction, dialogue and so smooth relationship between the student and the teacher. As cited in Scarlet (2015), Thomas Garden a psychologist has emphasized dialogues between teachers and students, which helps to foster the relationships and understand the relationship with the students. He has developed the concept I-message, which is known as I stated in the 1960s referring to clear interpersonal communication, particularly about the conflict area. It centers a person's feelings, beliefs, or values and always begins with I.

The students especially at the higher secondary level are in search of identity for not getting satisfied with what they get from parents and teachers. Therefore in our context, most students search for jobs, not only because they are in financial crisis, but also in search of establishing themselves as responsibility holders.

There are many students with disruptive behavior in public schools and more in the higher secondary level. That is because they are lacking basic needs and when basic needs are lacking 
Volume 2 (1) 2021

E-ISSN: 2723-6919 P-ISSN:2746-0827

we cannot expect students to concentrate on their studies. On the other hand, there are students of mixed abilities in the same class with several students high. Therefore the heterogeneous classroom with a traditional setting is a real challenge to the teachers at public schools. Therefore it is a must for the teachers to understand that there is nothing personal for students behaving such. When teachers understand this they will proceed on to manage the classroom. But classroom management is also a skill that needs to be developed through different training sessions which are lacking in our context.

There is a need to address local issues of poverty, multi-cultured and multi-lingual issues with the traditional practice of teaching-learning activities with the help of global theories developed. The local issues we have regarding these components need special focus. There is a need to conduct training sessions for the teachers of public schools based on motivation and classroom management addressing these local issues. Likewise, there is also a need of doing researches on this area and explore further gaps and progresses being made. The training courses teacher had got are outdated. New training packages addressing the modern issues of classroom management are in need.

\section{B. Methods}

The meanings and realities of classroom management have been developed through observation of the classroom where teaching-learning activities took place. The engagement of the learners, interest, and participatory classroom were the basic criteria to generate meaning. I wanted to see, how the global issues of classroom management are being put into practice locally, the shifts from past to now, and inquiry into the components of classroom management and analyze it based on a few of them. Additionally, reflective analysis of the classroom practices of the researcher herself is also part of the research. The data collection procedure is based on using observation as my tool.

As this research is based on the teaching practice of an EFL teacher teaching in class seven and class twelve, the teacher and students are participants. The classes of a female EFL teacher of public school were observed for a week. The comparison of classroom management practices of her in two levels: middle school and higher secondary level was done.

Her classes of teaching different forms of English as teaching passage, grammar, and poetry in these two levels were observed. The teacher was asked for permission to let observe and video record her classes after she was clarified about the purpose of the study.

Classroom management is an umbrella term that covers various other issues. Therefore there are few components based on which teacher's classes were observed and data analysis was done. The components are seating arrangements, discipline, peer work, group work, classroom interaction, ability grouping, presentation, and time management found in the school. The observation of the classes and reflective analysis showed.

The observed classes showed that the girls and boys have separate rows in middle school but with secondary level girls and boys are seated together. Similarly, the number of students on a bench varied; in some, there were three and in some four, in both the levels. There was no specific seat plan, however, a seating plan showing who sits where quickly enables teachers to learn and use individuals' names (Laslet \& Smith, 1992). This helps the teacher set fixed 
patterns in class. As most of the faces were familiar to the teacher, apart from the new ones, the names of students don't seem to be many problems to the teacher.

Different types of seating arrangements as paired desks, U-shaped, chevron for tables of four, and $\mathrm{u}$-shaped plus rows are suggested for better management of classroom globally. Nevertheless, those are not possible in our local context because of small-sized rooms and students more in numbers.

Usually, the seating plan was found fixed and there was a rotation system for students done by the teacher in middle school, with fixed bench partner; but in higher secondary level students themselves decided where to sit.

The classroom was so compact that it had no free space to move around. Students were compactly seated. The teacher was giving a lecture at the front of the class and other students especially backbenchers had been chatting and were not paying attention in the case of both the levels.

Students mostly in the higher secondary level were not paying attention at all. They were mostly found doing something else than listening or participating in classroom activities. They were caught with the mobile phone, talking to friends, sleeping or busy withdrawing or looking outside, etc. Whereas in middle English classes also the situation was the same. One day while the teacher was conducting group work including two benches of students in a group, only one or two students in a group were active. Others had been talking and not paying attention. The teacher didn't move freely throughout the class and was focusing only on the students who had been answering. I asked students if they used to play such language games, they answered no. They were taught and made to do given exercises only. Few were listening but not participating at all.

One of the students of class seven was angry at the teacher when she was asked a question in the classroom. It seemed that the student behaved rudely was for her presence not being valued as the teacher had been discussing only with the few active students that must have made her feel uncomfortable. The situation made me reflect on an incident when one of the students ignored answering my question. She argued with me. Later I talked to her and she replied to me that knowing a student has not understood why a teacher would ask and humiliate their knowledge? This made me read my students' faces. If they have understood, they have bright faces and if they are not they don't.

The teacher didn't make students work in pairs. Later I asked her and she said the number of students is big so that's too hard to manage. Though it is an effective way of developing selfdependency and making students autonomous because of the big number of students it was not possible to make them work.

Compared to pair work, group work was practiced. There is an unmanaged division of groups. As the classroom seating was traditional and unmanaged in number, the group formation seemed difficult. Though they were divided into groups, it was found that the students were not engaged in tasks and interaction. The classroom space is one of the hindrances in conducting group work. The other problem is students who were active respondents kept answering, but who were passive were not benefited. 
Forming a group and making them do any task is a challenging job in the classroom like this. Even at the secondary level, the passive students remain passive because the number of students in a group is not uniform.

Another day the teacher did reading comprehension. Students were asked to read. Though the groups had been formed, they read all alone. They read individually and there was no interaction between students at all. The later teacher herself elaborated the text as the students didn't do it. this showed that the strategies were lacking to make students speak rather than speaking themselves.

The teacher was found guided by the traditional method as in both the levels her classes were guided by the lecture method. Nonetheless, she made very good use of the whiteboard. She kept eye contact with the students but with almost limited. Active students were being focused as they were participating. Other students were quiet or busy doing something else. She was moving around the class but not much often because of the narrow space.

On the other hand presentation style in both the level was the same. The classroom was the same, i.e. the classroom where the students of middle school were taught, the class was the same for the secondary level too, with the same infrastructures and physical facilities. The classroom environment was the same as the same postures and pictures from middle school students.

There were no differences between the levels. The mass of students was as much as middle school or even more. The students on the last benches could not listen properly as they were being disturbed by the other few sitting around.

Apart from teaching the teachers are loaded with other responsibilities in a government school. The teacher was almost 3-5 minutes late regularly till I observed the class at the middle school level. It was because she was given responsibilities of students' management and by the time she came to her class, she was disturbed in between by some issues.

In higher secondary level she was working periodically so was on time, however, she directly entered inside the classroom and started teaching. No time allotment for pre-teaching and postteaching activities was there. Students' talk and discussion was missing throughout both the classes.

\section{Results and Discussion}

After a short research, based on a week classroom observation of an EFL teacher teaching in two levels in a school, on classroom management, I came up with the following findings. Students' were lacking disciplines or not having disciplines is because they are not being given value or not prioritized in the classroom.

Seat planning is a big challenge in our context, especially in public schools that have multiple abilities grouped in narrow and concise classrooms with a bench loaded with several students. Students are sitting so compact that it is difficult to conduct an activity-based classroom. There is no space between two benches to move around the classroom. Therefore teachers need to be taught to deal with these local contexts and strategies to handle the classroom with this seating plan. Management of time regarding students and students' talk is missing the most. 
Volume 2 (1) 2021

E-ISSN: 2723-6919 P-ISSN:2746-0827

The age of the learners is the other sensitive factor to be considered. The students of middle school are in the phase of identity change and accepting changes taking place within themselves. They want themselves to be recognized and paid attention to. Similarly, students of secondary level want themselves to be treated as a responsible mature learner. Therefore the teacher must be aware of keeping their identity as the focal point and not to hurt them or ignore them. Learners if are motivated time and again and focused in the classroom, will help them pay attention and establish themselves as good learners.

Time management is equally important for students' active participation as it is for content delivery. If the teacher misses allotting time for the learners the students will lose interest. The other factor is managing time for the pre, while, and post classroom activities in teaching. The consideration of this factor will help to manage class better ensuring a better learning environment.

When we use glocalized perspectives on classroom management, this will give a variety of exposure to alternatives that can be adopted. This is also flexible as we can adopt or share the practices we find relative in our context.

When the practices on classroom management are done is based on what we want to adopt in our context then, there is a higher chance of achievements to be made. Nevertheless, the context, culture, society, and politics need to be taken into higher consideration.

It teaches to respect other's cultures and values. What practices in India are done need not be the same in China as the choice depends on the need. But glocalization will teach to value others' practices and culture, and this will make others think on the issue critically. It's cheap to implement as the manpower is the teachers themselves to act is based on what is the need.

\section{Conclusion}

As said earlier, different schools have different practices regarding classroom management. Somewhere the management might have been working the best, whereas somewhere there might be the problem. For example, the problem regarding discipline persists with classroom management and this is the most crucial subject within it. The practices might have been done in some schools for such a complex situation and also might have been working, whereas somewhere the same technique might not work. This is where glocalization is needed.

Glocalization helps in sharing the practices and cultures, exploring the solutions to the problems being faced, blending global and local issues regarding the area (here classroom management). Furthermore, it helps in creating a community of sharing integrating cultural communities and teaching to respect others' culture and values. Glocalization of classroom management will help to better the classroom environment and provide quality, child-friendly education.

We are much like 'cat on the hot tin' in terms of the need for classroom management, and that too with glocalized version. We, therefore, need a careful selection of practices being made elsewhere with the help of expert advice, glocalization of issues regarding components of classroom management discussed above, which is also a research gap. Finally, recognizing glocalization as the immense need of meeting the $21^{\text {st }}$-century expansion of knowledge and classroom management a crucial issue to be thought about, we must think about the solutions 
Volume 2 (1) 2021

E-ISSN: 2723-6919 P-ISSN:2746-0827

to the challenges put forward by globalization and technologization. Nonetheless, this small research made me realize the need to train teachers on classroom management and glocalizing the concept of classroom management.

So still we found that the teachers are guided by the traditional way of teaching, thinking of themselves as a bank of knowledge and students just a receptor.

\section{E. Acknowledgement}

We thank to the Chancellor of the Mahendra Ratna Campus, Tahachal (TU) Nepal in completing this project.

\section{References}

Robertson, Roland. (1995) "Glocalization: Time-space and Homogeneity- heterogeneity", In M. Featherstone et al (Eds.), Global Modernities, (pp. 25-44). London: SAGE.

Khondker, H. H., (2004). Glocalization as Globalization: Evolution of a Sociological Concept. Bangladesh e-Journal of Sociology. 1(2), 12-20. Retrieved from http://www.bangladeshsociology.org/BEJS\%201.2\%20Issue\%20Habibul\%20Haque\% 20khondker.pdf

Patel. F \& Lynch, H. (2013). Glocalization as an Alternative to Internationalization in Higher Education: Embedding Positive Glocal Learning Perspectives. International Journal of Teaching and Learning in Higher Education. 25(2), 223-230. Retrieved from https://files.eric.ed.gov/fulltext/EJ1016539.pdf

Burns, A, \&Richards, J. C. (Eds.). (2009). The Cambridge Guide to Second Language Teacher Education. NY, USA: CUP.

Scarlett, W. G. (Ed.). (2015).The Sage Encyclopedia of Classroom Management. USA: SAGE.

Tauber, R. T. (Ed.). (2007). Classroom Management: Sound Theory and Effective Practice. USA: PRAEGER.

Smith, J. C. \& Laslett, R. (2002). Effective Classroom Management: A Teacher's Guide (2 ${ }^{\text {nd }}$ ed.). London, New York: Routledge.

Lewis, R. (2009). Understanding Pupil Behaviour: Classroom Management Techniques for Teachers. London, New York: Routledge.

Shindler, J. (2010). Transformative Classroom Management: Positive Strategies to Engage All Students and Promote a Psychology of Success. USA: Jossey-Bass.

Cummings, C. (2000). Winning Strategies for Classroom Management. USA: ASCD.

Nagler, K. S. (2016). Effective Classroom Management and Classroom Teaching. English Language Teaching. 9[1], 163-172. www.ccsenet.org/elt. 